\title{
Resistance of Geneva and Other Apple Rootstocks to Erwinia amylovora
}

\author{
J. L. Norelli, USDA-ARS, Appalachian Fruit Research Station, Kearneysville, WV 25430; H. T. Holleran, Depart- \\ ment of Horticultural Sciences, Cornell University, Geneva, NY 14456; W. C. Johnson, Seminis Vegetable Seeds, \\ Woodland, CA 95695; T. L. Robinson, Department of Horticultural Sciences; and H. S. Aldwinckle, Department \\ of Plant Pathology, Cornell University
}

\begin{abstract}
Norelli, J. L., Holleran, H. T., Johnson, W. C., Robinson, T. L., and Aldwinckle, H. S. 2003. Resistance of Geneva and other apple rootstocks to Erwinia amylovora. Plant Dis. 87:26-32

When vigorously growing shoots of 49 different apple rootstocks grown in a greenhouse were inoculated with different strains of Erwinia amylovora, Budagovsky 9 (B.9), Ottawa 3, Malling 9, and Malling 26 were the most fire blight susceptible rootstocks and Geneva 11, Geneva 65, Geneva 16, Geneva 30, Pillnitzer Au51-11, Malling 7, and several breeding selections were the most resistant. Significant strain-rootstock interactions were observed in the amount of fire blight that resulted from inoculation. Field-grown fruiting 'Royal Gala' trees on Geneva 16 and Geneva 30 rootstocks were highly resistant to rootstock infection (no tree mortality) when trees sustained severe blossom infection with E. amylovora, compared with Malling 9 and Malling 26 rootstock clones, which were highly susceptible to infection (36 to 100\% tree mortality). In contrast to potted own-rooted B.9 plants inoculated in a greenhouse, B.9 rootstocks of orchard trees appeared resistant to rootstock infection ( $0 \%$ tree mortality). Orchard trees on Geneva 11 were moderately resistant to rootstock infection ( $25 \%$ tree mortality). There was general agreement in the evaluation of resistance under orchard conditions when rootstock resistance was evaluated in relation to controlled blossom inoculation or to natural blossom infection.
\end{abstract}

Additional keywords: disease resistance, disease susceptibility, Malus

Fire blight, caused by Erwinia amylovora (Burrill) Winslow et al., is a destructive disease of apple that kills blossoms, shoots, and woody plant organs (23). Recently, fire blight of apple rootstocks has become a serious economic problem in high-density orchard systems (11). Over the past 50 years, most apple-growing regions have adopted the use of high-density orchard systems that depend upon dwarfing rootstocks to control tree size. The most commonly used dwarfing rootstocks, Malling (M.) 9 and M.26, are highly susceptible to E. amylovora and infection usually kills trees by girdling the rootstock. Several avenues of rootstock

Corresponding author: J. Norelli

E-mail: jnorelli@afrs.ars.usda.gov

This work was conducted at the New York State Agricultural Experiment Station, Cornell University, Geneva, NY while J. L. Norelli and W. C. Johnson were there as members of the Departments of Plant Pathology and the USDAARS, Plant Genetics Resources Unit, respectively. A USDA NE-Regional IPM grant and a USDA Special Grant on fire blight supported the research.

Accepted for publication 23 August 2002.

Publication no. D-2002-1028-02R

This article is in the public domain and not copyrightable. It may be freely reprinted with customary crediting of the source. The American Phytopathological Society, 2003. infection have been demonstrated, including infection of rootstock suckers (vegetative shoots developing from the rootstock), internal spread of bacteria from infections in the scion, or direct infection of the rootstocks through discontinuities in the bark caused by growth or various injuries (12). Currently, there are no effective cultural practices or chemical treatments available to control the rootstock phase of fire blight in high-density orchard systems.

The objective of the Geneva apple rootstock-breeding program has been to develop pomologically excellent rootstocks with resistance to abiotic and biotic stresses, including fire blight. The program was begun by J. N. Cummins, Department of Horticultural Sciences, Cornell University (Geneva, NY) in 1968. H. S. Aldwinckle, Department of Plant Pathology, Cornell University, joined the program in 1970. It became a joint program for the United States Department of Agriculture-Agricultural Research Service (USDA-ARS) and Cornell in 1998. Based upon inoculations with strain E. amylovora Ea273, Malus $\times$ robusta cv. Robusta 5 was identified as highly resistant to fire blight and was widely used as a parent in the Geneva breeding program (7). Repeated direct inoculation of actively growing shoot tips with E. amylovora strain Ea273 was used to identify resistant progeny of controlled crosses (8). Robusta 5 later was found to be differentially susceptible to infection by E. amylovora strain E4001a (also referred to as Ea266; 14,17,19). When rootstock selections were inoculated with strain E4001a or with a mixture of strains including E4001a, several rootstocks previously identified as resistant to strain Ea273 became severely infected and were discarded from the program $(15,16)$. Recently four apple rootstocks, Geneva (G.) 65, G.11, G.30, and G.16, were released for commercial sales (4). Several other selections are in the final stages of evaluation.

Although the Geneva rootstocks are known to be resistant to direct shoot inoculation with E. amylovora strains Ea273 or E4001a, it was not known if these apple rootstocks are resistant to natural infection by $E$. amylovora under orchard conditions or if they would be resistant to direct shoot inoculation with other highly aggressive strains of E. amylovora. The objectives of this study were to (i) compare the resistance of the Geneva rootstocks with that of other apple rootstocks when inoculated with the differentially virulent strain E4001a and other highly aggressive $E$. amylovora strains and (ii) evaluate the resistance of the Geneva rootstocks and advanced selections of the breeding program as rootstocks of grafted trees grown under orchard conditions.

\section{MATERIALS AND METHODS}

Bacterial strains and inoculum. $E$. amylovora strains used in this study are listed in Table 1. Inoculum consisted of 18h-old shake cultures grown in Kado 523 broth (9) at $28^{\circ} \mathrm{C}$. Inoculum concentration was estimated by absorbance at $620 \mathrm{~nm}$ using a standard curve and adjusted to the desired concentration by dilution with sterile $0.05 \mathrm{M}$ potassium phosphate buffer, $\mathrm{pH}$ 6.5. Inoculum was maintained on ice and was used for plant inoculation within 2 $\mathrm{h}$ of dilution.

Direct inoculation of ungrafted rootstock plants in greenhouse. The parentage of the apple rootstocks used in this study and the size of the tree they produce relative to the Malling series of rootstocks are described in Table 2 (13). Rootstocks were evaluated in the greenhouse for their resistance to fire blight by direct inoculation of vigorous shoots with one to four strains of E. amylovora (Tables 3 and 4). Stoolbed-propagated liners (rooted, hardwood shoot cuttings) obtained from vari- 
ous suppliers were potted in cylindrical pots $(5$ by $20 \mathrm{~cm})$ containing a peat and vermiculite soil mix, and trained to a single shoot. Vigorously growing shoots at least $15 \mathrm{~cm}$ in length were selected for inoculation. Due to a limited supply of many of the rootstocks, not all rootstocks were inoculated with all four strains. If less than 20 shoots were available for inoculations, a minimum of five shoots were inoculated with each individual strain. The priority of strain selection for shoot inoculation was first Ea273, then E2002a, then E4001a, and finally E2017p.

Shoots were inoculated on 16 June 2000 by transversally bisecting the two youngest actively growing leaves with scissors dipped in a suspension of a single strain of E. amylovora $\left(1 \times 10^{9} \mathrm{CFU} \mathrm{ml}^{-1}\right)$. Current season's shoot length and the length of the necrotic lesion were measured on 5 July 2000. The necrotic lesion length was expressed as a percentage of the current season's shoot length and used as the measure of host plant resistance. Individual plants were the unit of replication. GLM (SAS Institute Inc., Cary, NC) of the proportion of the shoot length necrotic was used to analyze treatment effects. Because the analysis indicated a significant rootstock by strain interaction, differences in rootstock resistance were analyzed for each strain using a Waller-Duncan $k$-ratio $t$ test.

Evaluation of rootstock resistance under orchard conditions following inoculation. Rootstocks of grafted fruiting trees were evaluated for their resistance to E. amylovora when grown in orchards subjected to an induced blossom blight epiphytotic (Table 5). Rootstock liners were planted in a nursery (spring 1995), bud chip grafted with the 'Royal Gala' scion (summer 1995), grown in the nursery for a second season, dug (fall 1996), graded, and stored. In spring 1997, an orchard was established at the Research North Farm of the New York State Agricultural Experiment Station (Geneva, NY) in a randomized block design that was blocked based upon trunk diameter measured immediately above the graft union on stored trees. Trees were grown under recommended commercial orchard practices, trained to a vertical axe (18), and provided with post support.

Trees at the Research North Farm all bloomed heavily in 1999 and open blos- soms were spray inoculated with E. amylovora strain E4001a using a backpack sprayer. Trees were inoculated twice (12 and 17 May 1999) to compensate for rootstock effects on the time of bloom and rootstock effects on the number of blossoms on 1-year-old wood, which tends to bloom later than spur blossoms. The inoculum concentration for the first inoculation was $1.0 \times 10^{7} \mathrm{CFU} / \mathrm{ml}$, but was reduced for the second inoculation to $1.4 \times$ $10^{6} \mathrm{CFU} / \mathrm{ml}$ due to the forecast of warmer weather conditions more favorable for blossom blight development.

Evaluation of rootstock resistance under orchard conditions following natural infection. Rootstocks of grafted fruiting trees also were evaluated for their resistance to E. amylovora after the occurrence of a natural blossom blight epiphytotic (Table 5). An orchard was established at Ray Smith Farm, Geneva, NY, as described above. Trees at the Ray Smith Farm bloomed heavily in 2000, and blossoms were heavily infected in May 2000 due to natural infection. Development of rootstock blight was recorded based upon the presence of bacterial ooze on rootstocks or typical fire blight necrosis of rootstock tissue with evidence of either tree death or premature leaf coloration in fall.

Differences among quantitative traits of the rootstocks (percent blossom clusters infected on scion) were analyzed using a generalized linear model and Waller-Duncan $k$-ratio $t$ test. Differences among nominal traits (presence or absence of rootstock blight symptoms) were analyzed using Ryan's (20) significance test for multiple comparison of proportions. Due to the nonparametric nature of the data and the limited size of the orchard trials, a type I error rate of $P=0.2$ was selected when testing the null hypothesis.

\section{RESULTS}

Direct inoculation of ungrafted rootstock plants in greenhouse. Budagovsky (B.) 9, Ottawa 3, M.9, and M.26 were the most fire blight susceptible rootstocks when vigorously growing shoots of ungrafted, own-rooted rootstock liners were inoculated with different strains of $E$. amylovora in the greenhouse (Table 3). B.9 had the greatest mean disease rating over all four strains and developed the greatest amount of fire blight among the rootstocks inoculated with strains Ea273, E4001a, and E2002a. G.11, G.65, G.16, G.30, Pillnitzer (Pi) Au51-11, M.7, and several advanced selections from the Geneva breeding program (CG) were the most resistant rootstocks when challenged by direct inoculation in the greenhouse. The Vineland rootstocks, Mark, Malling Merton (MM.) 106, M.27, Pi-Au56-83, Pi-Au51-4, some CG selections, Marubakaido, and other Japanese material were intermediate in their reaction to direct inoculation with $E$. amylovora.

Overall, strain E2002a caused the greatest amount of disease among the four strains used in the greenhouse inoculations (Table 3). Strain E4001a, which is differentially virulent to Malus $\times$ robusta Robusta 5 (15), caused a greater amount of disease on the resistant rootstocks than did either strain Ea273 or E2017p; however, it tended to cause less disease on susceptible rootstocks so that its overall mean virulence was similar to that of strains Ea273 and E2017p.

GLM analysis of the proportion of the shoot length that was necrotic indicated significant effects of rootstock and strain, and a significant rootstock-strain interaction on the amount of fire blight resulting from direct inoculation in the greenhouse (Table 4). Specific rootstock-strain interactions also were evident from changes in the resistance ranking of specific rootstocks when they were inoculated with different strains (Table 3). For example, when MM.106 EMLA (virus-tested clone developed at the East Malling and Long Ashton Research Stations, UK) was inoculated with either strain E4001a or strain E2002a, it was evaluated as relatively resistant and not significantly different from Marubakaido. However, when inoculated with either Ea273 or E2017p, MM.106 EMLA was evaluated as highly susceptible and not significantly different from B.9. Conversely, when Robusta 5 progeny CG.3007, CG.6879, and CG.6253 were inoculated with strain E4001a, they were ranked significantly more susceptible compared with other rootstocks than when they were inoculated with strain Ea273. However, there was no consistent pattern in the reaction of the Robusta 5 progeny to inoculation with strain E4001a. For example, CG.5087 and CG.4202 were ranked

Table 1. Strains of Erwinia amylovora used in this study

\begin{tabular}{|c|c|c|c|c|c|}
\hline \multirow[b]{2}{*}{ Strain } & \multicolumn{2}{|r|}{ Origin } & \multirow[b]{2}{*}{ Isolator } & \multirow[b]{2}{*}{ Characteristics } & \multirow[b]{2}{*}{ References } \\
\hline & Location & Host & & & \\
\hline E2002 $a^{y}$ & Ontario & Malus $\times$ domestica 'Jonathan' & W. G. Bonn & Highly aggressive strain & $14,17,19$ \\
\hline E2017p & Ontario & Pyrus communis 'Clapp's Favorite' & W. G. Bonn & Reported to be virulent to Geneva 16 & 3,19 \\
\hline $\mathrm{E} 4001 \mathrm{a}^{\mathrm{z}}$ & Ontario & Malus $\times$ domestica 'R.I. Greening' & W. G. Bonn & Differentially virulent to Malus $\times$ robusta 'Robusta 5 ' & $14,15,17$ \\
\hline $\mathrm{Ea} 273$ & New York & Malus $\times$ domestica 'R.I. Greening' & S. V. Beer & $\begin{array}{l}\text { Standard NY strain previously used for evaluation of } \\
\text { cultivar resistance }\end{array}$ & $1,14,21$ \\
\hline
\end{tabular}

\footnotetext{
y Also referred to as Ea265 $(14,17)$.
}

${ }^{z}$ Also referred to as Ea266 $(14,15,17)$. 
more resistant when inoculated with E4001a than when inoculated with Ea273. Like MM.106 EMLA, Supporter 4 was evaluated as highly susceptible when inoculated with the less aggressive strain Ea273, yet intermediate in its resistance when inoculated with the highly aggressive strain E2002a.

Evaluation of rootstock resistance under orchard conditions following inoculation. Based on blossom, leaf, and fruit characteristics, it was apparent that M.9 had not been grafted with Royal Gala but with 'McIntosh' or a cultivar closely resembling McIntosh. Blossom inoculation in May 1999 of orchard-grown Royal Gala trees (Research North Farm) on 3 Geneva rootstocks, 16 advanced Geneva selections (CG), and 7 other rootstocks with $E$. amylovora strain E4001a resulted in 5 to $23 \%$ of the blossom clusters infected. There was a significant effect of rootstock on the amount of blossom blight (Table 5).

Severe fire blight resulted from initial blossom infections with several lesions extending into 2-year-old wood on all trees. Several trees had lesions that extended into 3-year-old wood and the tree trunk; however, no visible scion infections extended to within $30 \mathrm{~cm}$ of the rootstock. Rootstock suckers of several trees developed symptoms typical of fire blight shoot infections; however, there were no significant differences among the rootstocks in the incidence of sucker infection (Table 5). Ooze typical of E. amylovora infection was first observed on rootstocks in the second week of June 1999. By 15 June 1999, 67 and $58 \%$ of the M.26 EMLA and M.9 trees, respectively, had ooze on the rootstock; however, only M.26 EMLA showed a significantly greater $(P=0.2)$ number of trees with oozing rootstocks (Table 5). For trees grafted on G.11, 17\% exhibited oozing rootstocks by 15 June 1999. For some rootstocks, such as Poland (P.) 14, CG.5012, and CG.103, the number of trees with oozing rootstocks continued to increase into July. By 8 July 1999 , necrosis typical of fire blight had developed on most of the rootstocks that had previously shown ooze and on some rootstocks on which ooze had not been detected. Again, only M.26 EMLA showed a significantly greater number of trees with necrosis compared with other rootstocks. Trees on CG.4003 and CG.60, and some trees on CG.5012, had signs of ooze on the rootstock but did not subsequently develop necrosis typical of fire blight. Several rootstocks, including G.16, G.30, MM.111, B.9, CG.3041, and CG.5179, had no evidence of fire blight infection on 8 July 1999 (Table 5).

By 9 September 1999, the symptoms of rootstock blight were apparent not only in rootstock tissue but also in tree scions that had either symptoms of tree death or premature leaf coloration (Table 5). At this date, greencolored leaves characterized healthy trees with
Table 2. Parentage of the apple rootstocks used in study and the size of the tree they produce relative to Malling (M.) and Malling Merton (MM.) rootstocks

\begin{tabular}{|c|c|c|}
\hline Rootstock $^{w}$ & Parentage & Tree size \\
\hline B.9 & M. $8 \times$ Red Standard ${ }^{x}$ & M.9 \\
\hline B.491 & Unknown & M.27 to M.9 \\
\hline CG.2 & Malus halliana $\times$ B.491 & M.9 to M.26 \\
\hline CG.8 & Unknown & Unknown \\
\hline CG.9 & M. $9 \times$ Sissipuk & M.26 \\
\hline CG.26 & M.7 × MM.106 & M.26 \\
\hline CG.48 & MM.111 × Alnarp 2 & M.27 to M.9 \\
\hline CG.60 & Novole $\times$ Poland 16 & Unknown \\
\hline CG.67 & Robusta $5 \times$ M. $9^{y}$ & M.26 \\
\hline CG.103 & M. $9 \times$ Robusta 5 & MM.111 \\
\hline CG.132 & Robusta $5 \times$ M.9 & M.7 \\
\hline CG.134 & CG. $24 \times$ Robusta 5 & MM.111 \\
\hline CG.602 & M.27 × Robusta 5 & M.26 \\
\hline CG.756 & Robusta $5 \times$ M.9 & MM.106 \\
\hline CG.3007 & Ottawa $3 \times$ Robusta 5 & M.9 \\
\hline CG.3029 & Dolgo Crab × M.9 & M.9 \\
\hline CG.3041 & M.27 (M.13 × M.9) X Robusta 5 & M.9 \\
\hline CG.4003 & (Antonovka Kamienaja $\times$ Ottawa 3 ) $\times$ Robusta 5 & M.26 \\
\hline CG.4013 & Ottawa $3 \times$ Novole & M.26 \\
\hline CG.4202 & M.27 × Robusta 5 & M.26 \\
\hline CG.4213 & Ottawa $3 \times$ Robusta 5 & M.26 \\
\hline CG.4214 & Ottawa $3 \times$ Robusta 5 & M.26 \\
\hline CG.4247 & Ottawa $3 \times$ Robusta 5 & M.26 \\
\hline CG.4814 & Ottawa $3 \times$ Robusta 5 & M.7 \\
\hline CG.5008 & $($ Novole $\times$ Ottawa 3$) \times$ M.9 & M.26 to M.7 \\
\hline CG.5012 & Ottawa $3 \times$ Robusta 5 & M.26 to M.7 \\
\hline CG.5046 & Novole $\times$ B.146 (unknown) & M.26 to M.7 \\
\hline CG.5087 & Ottawa $3 \times$ Robusta 5 & M.26 to M.7 \\
\hline CG.5156 & Robusta $5 \times$ M.9 & M.26 to M.7 \\
\hline CG.5179 & Ottawa $3 \times$ Robusta 5 & M.26 to M.7 \\
\hline CG.5757 & Ottawa $3 \times$ Robusta 5 & M.26 to M.7 \\
\hline CG.5890 & Ottawa $3 \times$ Robusta 5 & M.26 to M.7 \\
\hline CG.5935 & Ottawa $3 \times$ Robusta 5 & M.26 to M.7 \\
\hline CG.6143 & M.27 × Robusta 5 & M.7 \\
\hline CG.6210 & Ottawa $3 \times$ Robusta 5 & M.7 \\
\hline CG.6253 & Ottawa $3 \times$ Robusta 5 & M.7 \\
\hline CG.6589 & Novole $\times$ B.9 & M.7 \\
\hline CG.6723 & Ottawa $5 \times$ M.9 & M.7 \\
\hline CG.6737 & Robusta $5 \times$ M.9 & M.7 \\
\hline CG.6874 & Ottawa $3 \times$ Robusta 5 & M.7 \\
\hline CG.6879 & Robusta $5 \times$ M.9 & M.7 \\
\hline CG.6969 & Ottawa $3 \times$ Robusta 5 & M.7 \\
\hline CG.7707 & Robusta $5 \times$ M.9 & MM.106 \\
\hline CG.8228 & Robusta $5 \times$ M.9 & MM.111 \\
\hline Geneva 11 & M. $26 \times$ Robusta 5 & M.26 \\
\hline Geneva 16 & Ottawa $3 \times$ Malus floribunda & M.9 \\
\hline Geneva 30 & Robusta $5 \times$ M.9 & M.26 to M.7 \\
\hline Geneva 65 & M.27 × Beauty Crab & M.27 \\
\hline $\mathrm{J} .3$ & Unknown & Unknown \\
\hline JM.2 & Unknown & Unknown \\
\hline JM.4 & M. prunifolia 'Seishi' $\times$ M.9 & M.9 \\
\hline JM.10 & M. prunifolia 'Seishi' $\times$ M.9 & M.9 \\
\hline J-TE-B & Unknown & M.7 \\
\hline J-TE-C & Unknown & M.7 \\
\hline J-TE-D & Unknown & MM.106 \\
\hline M.7 & Unknown $^{\mathrm{x}}$ & M.7 \\
\hline M.9 & Unknown ${ }^{\mathrm{x}}$ & M.9 \\
\hline M.26 & M. $16 \times$ M..$^{\mathrm{x}}$ & M.26 \\
\hline M.27 EMLA & M.13 × M.9x & M.27 \\
\hline MM.106 & Northern Spy $\times$ M. $1^{\mathrm{x}}$ & MM.106 \\
\hline MM.111 & Northern Spy $\times$ Merton Immune $793\left(\right.$ Northern Spy $\times$ M.2) ${ }^{\mathrm{x}}$ & MM.111 \\
\hline EMLA & & \\
\hline Mark & M.9 open pollinated & M.27 to M.9 \\
\hline Marubakaido & Selection of M. prunifolia & Seedling \\
\hline Naga & Selection of $M$. prunifolia & Seedling \\
\hline Novole & Selection of M. prunifolia & Seedling \\
\hline \multicolumn{3}{|c|}{ (continued on next page) } \\
\hline
\end{tabular}

${ }^{\mathrm{w}}$ B. = Budagovsky; CG. = Cornell Geneva, advanced selection of Geneva apple rootstock breeding program; JM. = Japan, Morioka; J-TE = Jablon Technobuzice, Czech Republic; $\mathrm{Pi}=$ advanced selection of Pillnitzer.

x M.7, M.8, M.9, M.11, M.13, M.16, M.1, M.2, M.4 = English selection from a group of French genotypes known collectively as 'Jaune de Metz' in the late 1800s.

$\mathrm{y}$ Robusta 5 is a selection of Malus $\times$ robusta.

${ }^{\mathrm{z}}$ Pollen parent believed to be M.9. 
Table 2. (continued from preceding page)

\begin{tabular}{lll}
\hline Rootstock $^{\mathbf{w}}$ & \multicolumn{1}{c}{ Parentage } & \multicolumn{1}{c}{ Tree size } \\
\hline Ottawa 3 & Robin (hardy crab) $\times$ M.9 & M.26 \\
Pi-Au56-83 & M.11 open pollinated & M.9 \\
Pi-Au51-11 & M.4 open pollinated & M.26 \\
Pi-Au51-4 & M.4 open pollinated & M.26 \\
Poland 14 & M.9 open pollinated & M.26 \\
Supporter 4 & M.4 $\times$ M.9 & M.26 to M.7 \\
Vineland 1 & Kerr (Dolgo $\times$ Haralson) open pollinated & M.26 to M.7 \\
Vineland 2 & Kerr (Dolgo $\times$ Haralson) open pollinated & M.26 \\
Vineland 4 & Kerr (Dolgo $\times$ Haralson) open pollinated & MM.106 \\
Vineland 7 & Kerr (Dolgo $\times$ Haralson) open pollinated & M.7 \\
\hline
\end{tabular}

no evidence of rootstock blight, whereas many trees with fire blight-infected rootstocks had bronze-colored leaves. By September 1999, both M.26 EMLA and M.9 showed a significantly greater number of trees with rootstock blight symptoms than many other rootstocks, including MM.111, B.9, G.16, and G.30. Most trees that exhibited symptoms of rootstock infection in September 1999 died the following season, either failing to break dormancy in the spring or initially producing leaves that were small, often

Table 3. Severity of fire blight symptoms on 49 apple rootstocks inoculated with strains of Erwinia amylovora in greenhouse trial ${ }^{y}$

\begin{tabular}{|c|c|c|c|c|c|c|c|c|c|c|}
\hline \multirow[b]{3}{*}{ Rootstock $^{\mathrm{z}}$} & \multicolumn{8}{|c|}{ Strain of Erwinia amylovora } & & \\
\hline & \multicolumn{2}{|c|}{ Ea273 } & \multicolumn{2}{|r|}{ E2002a } & \multicolumn{2}{|r|}{ E4001a } & \multicolumn{2}{|c|}{ E2017p } & \multicolumn{2}{|c|}{ Cultivar mean } \\
\hline & $\mathbf{N}$ & $\%$ SLB & $\mathbf{N}$ & $\%$ SLB & $\mathbf{N}$ & $\%$ SLB & $\mathbf{N}$ & $\%$ SLB & $\mathbf{N}$ & $\%$ SLB \\
\hline Budagovsky 9 & 10 & $93.3 \mathrm{a}$ & 10 & $97.5 \mathrm{a}$ & 7 & $73.9 \mathrm{a}$ & 9 & $82.8 \mathrm{ab}$ & 36 & 88.1 \\
\hline Ottawa 3 & 7 & $84.4 \mathrm{ab}$ & 6 & $89.2 \mathrm{abc}$ & $\ldots$ & & $\ldots$ & $\ldots$ & 13 & 86.6 \\
\hline M.9 EMLA & 6 & $91.0 \mathrm{a}$ & 6 & $95.6 \mathrm{ab}$ & 6 & $72.7 \mathrm{a}$ & $\ldots$ & $\ldots$ & 18 & 86.4 \\
\hline M.26 EMLA & 6 & $83.4 \mathrm{ab}$ & 6 & 74.4 bcdefg & $\ldots$ & $\ldots$ & $\ldots$ & $\cdots$ & 12 & 78.9 \\
\hline J-TE-D & 5 & $76.9 \mathrm{abc}$ & $\ldots$ & $\ldots$ & $\ldots$ & $\ldots$ & $\ldots$ & $\ldots$ & 5 & 76.9 \\
\hline Budagovsky 491 & 6 & $75.8 \mathrm{abcd}$ & $\ldots$ & $\ldots$ & $\ldots$ & $\ldots$ & $\ldots$ & $\ldots$ & 6 & 75.8 \\
\hline Supporter 4 & 7 & $80.3 \mathrm{abc}$ & 7 & 57.1 efghijkl & $\ldots$ & $\ldots$ & $\ldots$ & $\ldots$ & 14 & 68.7 \\
\hline MM.106 EMLA & 5 & $84.5 \mathrm{ab}$ & 5 & 62.9 defghij & 5 & 35.3 cdefghijkl & 5 & $91.0 \mathrm{a}$ & 20 & 68.4 \\
\hline M.27 EMLA & 7 & 68.2 bcde & $\ldots$ & $\ldots$ & $\ldots$ & $\ldots$ & $\ldots$ & $\ldots$ & 7 & 68.2 \\
\hline JM.10 & 8 & 55.0 defg & 7 & $92.6 \mathrm{ab}$ & 7 & 28.9 fghijlkm & 7 & $88.9 \mathrm{a}$ & 29 & 65.9 \\
\hline Pi-Au56-83 & 7 & 58.5 cdefg & 8 & 77.2 abcdef & 7 & 58.0 abcde & $\ldots$ & $\ldots$ & 22 & 65.1 \\
\hline Pi-Au51-4 & 5 & $48.4 \mathrm{efgh}$ & 5 & 78.5 abcde & $\ldots$ & $\ldots$ & $\ldots$ & $\ldots$ & 10 & 63.5 \\
\hline CG.3007 & 6 & 37.8 fghij & 5 & $92.0 \mathrm{abc}$ & 5 & $61.6 \mathrm{abcd}$ & $\ldots$ & $\ldots$ & 16 & 62.2 \\
\hline CG.6879 & 6 & 30.5 hijkl & 6 & $92.7 \mathrm{ab}$ & $\ldots$ & $\ldots$ & $\ldots$ & $\ldots$ & 12 & 61.6 \\
\hline J-TE-C & 5 & $50.2 \mathrm{efgh}$ & 6 & 69.6 cdefgh & 5 & $62.8 \mathrm{abc}$ & $\ldots$ & $\ldots$ & 16 & 61.4 \\
\hline Mark & 8 & 37.6 ghij & 7 & 59.1 efghijk & 7 & 56.4 abcdef & 7 & $80.6 \mathrm{ab}$ & 29 & 57.7 \\
\hline J.3 & $\ldots$ & $\ldots$ & 6 & 53.3 ghijklmn & $\ldots$ & & $\ldots$ & $\ldots$ & 6 & 53.3 \\
\hline Vineland 2 & 6 & 39.1 fghij & 6 & 54.6 ghijklmn & 6 & 54.2 abcdefg & 5 & $66.8 \mathrm{~b}$ & 23 & 53.1 \\
\hline CG.5087 & 6 & $59.6 \mathrm{cdef}$ & 6 & 62.3 defghij & 5 & 33.3 defghijklm & $\ldots$ & $\ldots$ & 17 & 52.8 \\
\hline JM.2 & 8 & $51.3 \mathrm{efgh}$ & $\ldots$ & $\ldots$ & $\ldots$ & $\ldots$ & $\ldots$ & $\ldots$ & 8 & 51.3 \\
\hline JM.4 & 7 & $46.2 \mathrm{fghi}$ & 6 & 63.1 defghij & 6 & 43.9 cdefghij & & & 19 & 50.8 \\
\hline CG.6253 & 5 & $23.0 \mathrm{jklmn}$ & 4 & 83.0 abcd & & & & & 9 & 49.6 \\
\hline J-TE-B & 6 & $47.5 \mathrm{efgh}$ & 5 & 64.4 defghi & 5 & 34.8 cdefghijkl & & & 16 & 48.8 \\
\hline Vineland 7 & 6 & $47.6 \mathrm{efgh}$ & & & $\ldots$ & $\ldots$ & $\ldots$ & $\ldots$ & $\ldots$ & \\
\hline Vineland 1 & 5 & 32.1 hijk & 5 & 55.2 fghijklm & $\ldots$ & $\ldots$ & $\ldots$ & $\ldots$ & 10 & 43.7 \\
\hline CG.6210 & 7 & 38.3 fghij & $\ldots$ & $\ldots$ & $\ldots$ & $\ldots$ & $\ldots$ & $\ldots$ & 7 & 38.3 \\
\hline CG.4013 & 7 & 14.9 klmno & 8 & 51.3 hijklmno & 7 & 46.7 abcdefghi & 8 & $36.1 \mathrm{c}$ & 30 & 37.7 \\
\hline Marubakaido & 9 & 13.8 klmno & 10 & 62.5 defghij & 10 & 45.3 bcdefghi & 9 & $24.9 \mathrm{~cd}$ & 38 & 37.5 \\
\hline Vineland 4 & 7 & 24.5 ijklm & 7 & 36.7 klmnopqr & 6 & 48.6 abcdefgh & 6 & $38.1 \mathrm{c}$ & 26 & 36.5 \\
\hline Naga & 6 & $7.1 \mathrm{mno}$ & 6 & 50.1 hijklmno & 6 & 44.3 cdefghij & $\ldots$ & $\ldots$ & 18 & 33.8 \\
\hline CG.5046 & 5 & $0.0 \mathrm{o}$ & 5 & 49.9 hijklmno & 5 & 38.7 cdefghij & $\ldots$ & $\ldots$ & 15 & 29.5 \\
\hline CG.4202 & 7 & 31.1 hijk & 7 & 43.6 ijklmnop & 7 & 21.0 hijklm & 7 & $18.7 \mathrm{de}$ & 28 & 28.6 \\
\hline M.7 EMLA & 6 & $12.0 \mathrm{klmno}$ & 6 & 42.4 ijklmnopq & 6 & 45.1 bcdefghij & 6 & $11.0 \mathrm{de}$ & 24 & 27.6 \\
\hline CG.5890 & 8 & $6.0 \mathrm{mno}$ & 9 & 47.4 hijklmnop & 8 & 36.4 cdefghij & 8 & $16.9 \mathrm{de}$ & 33 & 27.3 \\
\hline CG.5179 & 5 & $0.0 \mathrm{o}$ & 5 & 46.6 ijklmnop & 5 & 33.5 defghijklm & $\ldots$ & $\ldots$ & 15 & 26.7 \\
\hline CG.5935 & 7 & $5.8 \mathrm{mno}$ & 7 & 56.2 efghijkl & 6 & 30.1 efghijklm & 6 & $5.9 \mathrm{ef}$ & 26 & 25.0 \\
\hline CG.7707 & 6 & 9.1 lmno & 6 & 32.6 nopqr & 6 & 26.8 ghijklm & $\ldots$ & $\ldots$ & 18 & 22.9 \\
\hline Geneva 30 & 8 & $0.7 \mathrm{o}$ & 8 & 44.8 ijklmnop & 7 & 39.2 cdefghij & 7 & $5.0 \mathrm{ef}$ & 30 & 22.4 \\
\hline CG.4003 & 9 & $0.0 \mathrm{o}$ & 8 & 41.0 jklmnopq & 9 & 39.5 cdefghijk & 8 & $4.8 \mathrm{ef}$ & 34 & 21.2 \\
\hline CG.5757 & 5 & $0.0 \mathrm{o}$ & 5 & 49.4 hijklmno & 5 & $13.9 \mathrm{klm}$ & $\ldots$ & $\ldots$ & 15 & 21.1 \\
\hline CG.6969 & 7 & $1.0 \mathrm{o}$ & 7 & 37.3 klmnopqr & 5 & 26.6 ghijklm & $\ldots$ & $\ldots$ & 19 & 21.1 \\
\hline Geneva 16 & 9 & 1.1 no & 8 & 45.8 ijklmnop & 8 & $18.4 \mathrm{ijklm}$ & 8 & $9.5 \mathrm{def}$ & 33 & 18.2 \\
\hline Pi-Au51-11 & 6 & $6.1 \mathrm{mno}$ & 5 & 30.7 opqr & $\ldots$ & $\ldots$ & $\ldots$ & $\ldots$ & 11 & 17.3 \\
\hline CG.6589 & 8 & $0.0 \mathrm{o}$ & 8 & 34.9 lmnopqr & 7 & $16.7 \mathrm{jklm}$ & $\ldots$ & $\ldots$ & 23 & 17.2 \\
\hline CG.6874 & 6 & 10.4 klmno & 5 & $25.1 \mathrm{pqr}$ & $\ldots$ & & $\ldots$ & $\ldots$ & 11 & 17.1 \\
\hline Geneva 65 & 8 & $0.0 \mathrm{o}$ & 7 & 32.9 mnopqr & 7 & 25.8 ghijklm & 7 & $7.1 \mathrm{ef}$ & 29 & 15.9 \\
\hline CG.4814 & 7 & $0.0 \mathrm{o}$ & 6 & $21.0 \mathrm{pqr}$ & 6 & $7.5 \mathrm{~lm}$ & $\ldots$ & $\ldots$ & 19 & 9.0 \\
\hline CG.3041 & 4 & $0.0 \mathrm{o}$ & 5 & $17.2 \mathrm{r}$ & 5 & $5.2 \mathrm{~m}$ & $\ldots$ & $\ldots$ & 14 & 8.0 \\
\hline Geneva 11 & 7 & 1.7 no & 7 & $14.9 \mathrm{r}$ & 7 & $12.8 \mathrm{klm}$ & 7 & $0.0 \mathrm{f}$ & 28 & 7.4 \\
\hline Strain mean & 317 & 33.4 & 277 & 56.4 & 209 & 37.7 & 120 & 33.6 & 923 & 41.2 \\
\hline
\end{tabular}

${ }^{y} \mathrm{~N}=$ number of plants inoculated and \% SLB = mean percent of the current season's shoot length that became necrotic after inoculation. Means within a column followed by the same letter did not differ significantly at $P=0.05$ according to a Waller and Duncan's $k$-ratio $t$ test.

${ }^{\mathrm{z}}$ M. = Malling; MM. = Malling Merton; JM. = Japan, Morioka; J-TE = Jablon Technobuzice, Czech Republic; Pi $=$ advanced selection of Pillnitzer; CG. = Cornell Geneva, advanced selection of Geneva apple rootstock breeding program; EMLA = virus-tested clones developed at the East Malling and Long Ashton Research Stations, UK. 
chlorotic, and failing to continue growth. Notable exceptions were one tree of CG.3041 and one tree of CG.5179, which had typical fire blight necrosis on 80 and $100 \%$, respectively, of the rootstock circumference in September 1999, but grew normally during the 2000 growing season. One tree on MM.111 was dead on 18 May 2000, but there were no symptoms typical of fire blight associated with the rootstock and it was presumed to have died from other causes. Although the block was not pruned during the 1999-2000 winter, only light blossom infection occurred in the 2000 season. Additional trees on M.26, M.9, CG.5012, CG.5179, CG.602, and CG.6737 continued to develop symptoms of fire blight rootstock infection during the 2000 season (Table 5). der orchard conditions following natural infection. During the 2000 growing season, an epiphytotic of rootstock blight resulting from natural blossom infection occurred in another trial of Geneva rootstocks planted in a commercial orchard at Geneva, NY (Ray Smith Farm). All Gala trees within the block sustained blossom infection and most trees had over $50 \%$ of the blossom clusters infected. Blocks of Jonagold, Spartan, and Cortland trees on M.9 rootstock adjacent to the trial sustained 60 to $80 \%$ incidence of rootstock blight. Generally, the incidence of rootstock blight resulting from natural blossom infection in the scion was in close agreement with the results obtained following spray inoculation during bloom (Table 5). Differences between natural and spray blossom inoculation trials included a higher incidence of rootstock infection in the natural blossom infection block in MM.111 and P. 14, and a lower incidence in M.9, CG.5012, and CG.5179. As in the spray-inoculated blocks, trees on M.9 were not grafted with Royal Gala. Of 24 trees on G.30 in the natural infection block, 1 had symptoms of rootstock blight on 14 October 2000. As in the spray-inoculation block, in the natural-infection block no tree on B.9 showed evidence of rootstock infection and $23 \%$ of trees on G.11 had evidence of rootstock blight (Table 5).

\section{DISCUSSION}

When shoots of rootstock cultivars were inoculated with different strains of E. amy-
Evaluation of rootstock resistance un-

lovora, significant strain-rootstock interactions were observed in the amount of fire blight that resulted from inoculation. Those interactions were clearly differential and could not be explained by the greater aggressiveness of strain E2002a because some rootstocks (e.g., MM.106, Supporter 4) were evaluated as significantly more susceptible when inoculated with the less aggressive strain Ea273 than when inoculated with the highly aggressive strain E2002a (Table 3). Previous research had determined that strain E4001a is differentially virulent to specific resistant cultivars, such as 'Quinte', 'Novole', and Robusta 5 $(14,15)$. Unfortunately, liners of Quinte, Novole, and Robusta 5 were not available for inclusion in these tests. Consistent with previous reports, strain E2002a was clearly more aggressive than either strain Ea273 or E4001a $(14,17)$. The virulence pattern of E2017p was more similar to that of Ea273 than that of E4001a.

G.11, G.30, G.16, G.65, and most CG selections were resistant to all four strains used for inoculation in a nondifferential manner, even though many, including G.11 and G.30, are progeny of Robusta 5, which is known to be differentially susceptible to strain E4001a. These rootstocks were selected or evaluated with a pooled mixture of different strains, and their resistance to individual strains indicates that pooled strains of E. amylovora can be used successfully to select for resistance to several strains of differing virulence (16). Resistance effective against strains of different virulence patterns (or races) should be more durable than that selected against a single strain.

Although there were dramatic differences among the rootstocks in the development of rootstock blight symptoms under orchard conditions, there was relatively little statistical separation of rootstock resistance in orchard trials due to the nonparametric nature of the data and financial constraints that limited the size of the field plantings. Because of these limitations, a relatively high error rate probability of 0.2 was selected for comparison of rootstock resistance in the orchard trial. Differences in the amount of blossom cluster infection that resulted from blossom inoculation of the Royal Gala scion on different rootstocks could not be explained by any obvious biological factor such as amount of

Table 4. Generalized linear model analysis of severity of fire blight symptoms on 49 apple rootstocks inoculated with strains of Erwinia amylovora in greenhouse trial

\begin{tabular}{lccc}
\hline Source of variation & Degrees of freedom & Sums of square & $\boldsymbol{F}^{\mathbf{z}}$ \\
\hline Model & 138 & 68.580 & $10.65^{* *}$ \\
Error & 784 & 36.909 & $\ldots$ \\
Corrected total & 922 & 105.489 & $\ldots$ \\
Type III error & & & \\
Rootstock & 47 & 47.086 & $21.28^{* *}$ \\
Strain & 3 & 9.300 & $65.85^{* *}$ \\
Rootstock $\times$ strain & 88 & 11.803 & $2.85^{* *}$ \\
\hline
\end{tabular}

$\mathrm{z}$ *** Denotes statistical significance, $P=0.01$. bloom, time of bloom, tree size, or susceptibility of the rootstock. Aldwinckle et al. (2) previously have reported an effect of rootstock clone on the susceptibility of scion shoots to direct inoculation with $E$. amylovora.

CG.3041 (ready for commercial release), G.16, and G.30 all had very high levels of resistance to E. amylovora in both greenhouse and orchard trials. Considering the high level of resistance of G.11 against all strains of $E$. amylovora in the greenhouse trial, it developed more disease than expected in both orchard trials (approximately 25\% of the trees diseased). However, compared with disease development in M.9 and M.26 clones (70 to $100 \%$ tree death in the blossom inoculated trial), the level of resistance in G.11 should be commercially useful under conditions of lower disease pressure.

B.9 was evaluated as the most susceptible rootstock when vegetative shoots of rootstock liners were inoculated in the greenhouse (Table 3) but, surprisingly, it did not develop any rootstock blight in either orchard trial (Table 5). Visual comparison of leaf, flower, and fruit morphology between B.9 trees grown in the USDA-ARS Plant Genetic Resources Unit germ plasm collection (Geneva, NY) and a B.9 rootstock sucker that flowered and developed fruit in 2000 in the Experiment Station trial provided no indication that the material in our trial was not authentic B.9. In addition, trees grown on B.9 in our trials appeared consistent with expected tree size, yield, and general appearance for trees grown on B.9. However, it is still possible that there may be different genotypes labeled as B.9 in commercial and research stoolbeds. A high level of orchard resistance has been reported for trees grown on B.9 rootstock in Ohio, where rootstock blight resulted in losses of up to $67 \%$ of the trees on M.26 rootstock but none of the trees on B.9 were lost due to fire blight $(5,6)$. Mortality of trees on B.9 rootstock has been reported in the NC140 trials; however, the cause of tree death usually was not reported and it is possible that these trees may have died from other causes (10).

The varying response of B.9 and G.11 as grafted orchard trees compared with ungrafted liners in the greenhouse may be due to altered susceptibility of the rootstocks when challenged by a different avenue of infection, such as systemic movement of internal bacteria (12) or by changes in rootstock physiology when the rootstock was grafted under scions and grown as fruiting trees (22). The high severity of fire blight observed in an infected rootstock sucker of G.11 in the orchard compared with the low disease severity in an infected B.9 sucker (Table 5) suggests the latter possibility (that growth under orchard conditions may alter susceptibility) because rootstock sucker infection should 
Table 5. Fire blight symptoms observed on scions ('Royal Gala') and rootstocks grown under orchard conditions ${ }^{\mathrm{n}}$

\begin{tabular}{|c|c|c|c|c|c|c|c|c|c|c|c|c|}
\hline \multirow[b]{4}{*}{ Rootstock } & \multicolumn{10}{|c|}{ Inoculated trial $^{\circ}$} & & \\
\hline & \multirow[b]{3}{*}{$\mathbf{N}$} & \multicolumn{7}{|c|}{1999} & \multicolumn{2}{|c|}{2000} & \multicolumn{2}{|c|}{ Natural $^{p}$} \\
\hline & & \multirow{2}{*}{$\begin{array}{l}\text { Blossom } \\
\text { cluster }^{t}\end{array}$} & \multicolumn{2}{|c|}{ Rootstock suckers } & \multicolumn{2}{|c|}{ Ooze $^{q}$} & \multicolumn{2}{|c|}{ Blight $^{r}$} & \multirow{2}{*}{$\begin{array}{c}\text { Dead }^{\mathrm{s}} \\
5 / 18\end{array}$} & \multirow{2}{*}{$\frac{\text { Blight }^{\mathrm{r}}}{9 / 14}$} & \multirow[b]{2}{*}{$\mathbf{N}$} & \multirow{2}{*}{$\frac{\text { Blight }^{\mathrm{r}}}{10 / 14 / 00}$} \\
\hline & & & Tree $^{\mathrm{u}}$ & $\overline{\text { Shoot }^{v}}$ & $6 / 15$ & $7 / 8$ & $7 / 8$ & $9 / 9$ & & & & \\
\hline M.26 EMLA & 12 & 12 defgh & $17 \mathrm{a}$ & 100 & $67 \mathrm{a}$ & $58 \mathrm{a}$ & $75 \mathrm{a}$ & $92 \mathrm{a}$ & $92 \mathrm{a}$ & $100 \mathrm{a}$ & 14 & $93 \mathrm{a}$ \\
\hline M.26 VF & 10 & $13 \mathrm{cdef}$ & $30 \mathrm{a}$ & 100 & $30 \mathrm{ab}$ & $20 \mathrm{a}$ & $30 \mathrm{ab}$ & $60 a b c$ & $60 a b c$ & $70 \mathrm{abc}$ & 14 & $57 \mathrm{ab}$ \\
\hline M.26 C & $\ldots$ & $\ldots$ & $\ldots$ & $\ldots$ & $\ldots$ & $\ldots$ & $\ldots$ & $\ldots$ & $\ldots$ & $\ldots$ & 13 & $69 \mathrm{ab}$ \\
\hline M.9 VF ('McIntosh')w & 12 & 11 defgh & $17 \mathrm{a}$ & 93 & $58 \mathrm{ab}$ & $58 \mathrm{a}$ & $58 \mathrm{ab}$ & $83 \mathrm{ab}$ & $83 \mathrm{ab}$ & $100 \mathrm{a}$ & 11 & $36 \mathrm{ab}$ \\
\hline M.7 & $\ldots$ & $\ldots$ & $\ldots$ & $\ldots$ & $\ldots$ & $\ldots$ & $\ldots$ & $\ldots$ & $\ldots$ & $\ldots$ & 13 & $31 \mathrm{ab}$ \\
\hline MM.106 & $\ldots$ & $\ldots$ & $\ldots$ & $\ldots$ & $\ldots$ & $\ldots$ & $\ldots$ & $\ldots$ & $\ldots$ & $\ldots$ & 14 & $43 \mathrm{ab}$ \\
\hline MM.111 EMLA & 12 & $11 \mathrm{efgh}$ & $0 \mathrm{a}$ & 0 & $0 \mathrm{~b}$ & $0 \mathrm{a}$ & $0 \mathrm{~b}$ & $0 \mathrm{c}$ & $8 \mathrm{c}$ & $0 c^{x}$ & 13 & $15 \mathrm{ab}$ \\
\hline Marubakiado & 12 & $23 \mathrm{a}$ & $17 \mathrm{a}$ & 75 & $0 \mathrm{~b}$ & $8 \mathrm{a}$ & $0 \mathrm{~b}$ & $0 \mathrm{c}$ & $0 \mathrm{c}$ & $0 \mathrm{c}$ & 14 & $0 \mathrm{~b}$ \\
\hline Budagovsky 9 & 12 & $18 \mathrm{bc}$ & $8 \mathrm{a}$ & 5 & $0 \mathrm{~b}$ & $0 \mathrm{a}$ & $0 \mathrm{~b}$ & $0 \mathrm{c}$ & $0 \mathrm{c}$ & $0 \mathrm{c}$ & 14 & $0 \mathrm{~b}$ \\
\hline Poland 14 & 7 & $13 \mathrm{cdef}$ & $14 \mathrm{a}$ & 83 & $0 \mathrm{~b}$ & $29 a$ & $0 \mathrm{~b}$ & $29 \mathrm{abc}$ & $29 a b c$ & $29 \mathrm{c}$ & 11 & $73 \mathrm{ab}$ \\
\hline Geneva 11 & 12 & 15 bcde & $8 \mathrm{a}$ & 100 & $17 \mathrm{ab}$ & $17 \mathrm{a}$ & $17 \mathrm{~b}$ & $25 \mathrm{bc}$ & $25 \mathrm{bc}$ & $25 \mathrm{c}$ & 13 & $23 \mathrm{ab}$ \\
\hline Geneva 16 & 6 & $16 \mathrm{bcd}$ & $17 \mathrm{a}$ & 75 & $0 \mathrm{~b}$ & $0 \mathrm{a}$ & $0 \mathrm{~b}$ & $0 \mathrm{c}$ & $0 \mathrm{c}$ & $0 \mathrm{c}$ & 19 & $0 \mathrm{~b}$ \\
\hline Geneva 30 & 18 & 10 efgh & $11 \mathrm{a}$ & 9 & $0 \mathrm{~b}$ & $6 \mathrm{a}$ & $0 \mathrm{~b}$ & $0 \mathrm{c}$ & $0 \mathrm{c}$ & $0 \mathrm{c}$ & 24 & $4 \mathrm{~b}$ \\
\hline Novole & $\ldots$ & $\ldots$ & $\ldots$ & $\ldots$ & $\ldots$ & $\ldots$ & $\ldots$ & $\ldots$ & $\ldots$ & $\ldots$ & 5 & $0 \mathrm{~b}$ \\
\hline CG.3007 & $\ldots$ & $\ldots$ & $\ldots$ & $\ldots$ & $\ldots$ & $\ldots$ & $\ldots$ & $\ldots$ & $\ldots$ & $\ldots$ & 12 & $0 \mathrm{~b}$ \\
\hline CG.3041 & 12 & 15 bcde & $0 \mathrm{a}$ & 0 & $0 \mathrm{~b}$ & $0 \mathrm{a}$ & $0 \mathrm{~b}$ & $8 \mathrm{c}$ & $0 \mathrm{c}$ & $0 \mathrm{c}^{\mathrm{y}}$ & 13 & $0 \mathrm{~b}$ \\
\hline CG.4003 & 12 & $7 \mathrm{hi}$ & $8 \mathrm{a}$ & 67 & $8 \mathrm{~b}$ & $0 \mathrm{a}$ & $0 \mathrm{~b}$ & $0 \mathrm{c}$ & $0 \mathrm{c}$ & $0 \mathrm{c}$ & 13 & $8 \mathrm{~b}$ \\
\hline CG.4202 & 12 & 7 ghi & $8 \mathrm{a}$ & 36 & $0 \mathrm{~b}$ & $0 \mathrm{a}$ & $0 \mathrm{~b}$ & $8 \mathrm{c}$ & $0 \mathrm{c}$ & $0 \mathrm{c}^{\mathrm{y}}$ & 27 & $7 \mathrm{~b}$ \\
\hline CG.4213 & $\ldots$ & $\ldots$ & $\ldots$ & $\ldots$ & $\ldots$ & $\ldots$ & $\ldots$ & $\ldots$ & $\ldots$ & $\ldots$ & 6 & $0 \mathrm{~b}$ \\
\hline CG.4214 & 6 & 9 fghi & $0 \mathrm{a}$ & 0 & $0 \mathrm{~b}$ & $0 \mathrm{a}$ & $0 \mathrm{~b}$ & $0 \mathrm{c}$ & $0 \mathrm{c}$ & $0 \mathrm{c}$ & 13 & $0 \mathrm{~b}$ \\
\hline CG.4247 & 11 & 12 defgh & $0 \mathrm{a}$ & 0 & $0 \mathrm{~b}$ & $0 \mathrm{a}$ & $0 \mathrm{~b}$ & $0 \mathrm{c}$ & $0 \mathrm{c}$ & $0 \mathrm{c}$ & 12 & $0 \mathrm{~b}$ \\
\hline CG.4814 & $\ldots$ & $\ldots$ & $\ldots$ & $\ldots$ & $\ldots$ & $\ldots$ & $\ldots$ & $\ldots$ & $\ldots$ & $\ldots$ & 12 & $0 \mathrm{~b}$ \\
\hline CG.5012 & 9 & 12 defgh & $33 \mathrm{a}$ & 76 & $0 \mathrm{~b}$ & $33 a$ & $0 \mathrm{~b}$ & $11 \mathrm{c}$ & $11 \mathrm{c}$ & $44 a b c$ & 13 & $0 \mathrm{~b}$ \\
\hline CG.5046 & $\ldots$ & $\ldots$ & $\ldots$ & $\ldots$ & $\ldots$ & $\ldots$ & $\ldots$ & $\ldots$ & $\ldots$ & $\ldots$ & 13 & $15 \mathrm{ab}$ \\
\hline CG.5179 & 12 & 12 defgh & $0 \mathrm{a}$ & 0 & $0 \mathrm{~b}$ & $0 \mathrm{a}$ & $0 \mathrm{~b}$ & $8 \mathrm{c}$ & $8 \mathrm{c}$ & $17 \mathrm{c}$ & 11 & $0 \mathrm{~b}$ \\
\hline CG.5757 & 12 & 12 defg & $17 \mathrm{a}$ & 85 & $0 \mathrm{~b}$ & $0 \mathrm{a}$ & $0 \mathrm{~b}$ & $0 \mathrm{c}$ & $0 \mathrm{c}$ & $8 \mathrm{c}$ & 13 & $0 \mathrm{~b}$ \\
\hline CG.6143 & $\ldots$ & $\ldots$ & $\ldots$ & $\ldots$ & $\ldots$ & $\ldots$ & $\ldots$ & $\ldots$ & $\ldots$ & $\ldots$ & 12 & $42 \mathrm{ab}$ \\
\hline CG. 6210 & $\ldots$ & $\ldots$ & $\ldots$ & $\ldots$ & $\ldots$ & $\ldots$ & $\ldots$ & $\ldots$ & $\ldots$ & $\ldots$ & 14 & $7 \mathrm{~b}$ \\
\hline CG.6253 & $\ldots$ & $\ldots$ & $\ldots$ & $\ldots$ & $\ldots$ & $\ldots$ & $\ldots$ & $\ldots$ & $\ldots$ & $\ldots$ & 9 & $0 \mathrm{~b}$ \\
\hline CG.2 (dis) $)^{\mathrm{z}}$ & $\ldots$ & $\ldots$ & $\ldots$ & $\ldots$ & $\ldots$ & $\ldots$ & $\ldots$ & $\ldots$ & $\ldots$ & $\ldots$ & 7 & $0 \mathrm{~b}$ \\
\hline CG.8 (dis) & $\ldots$ & $\ldots$ & $\ldots$ & $\ldots$ & $\ldots$ & $\ldots$ & $\ldots$ & $\ldots$ & $\ldots$ & $\ldots$ & 14 & $0 \mathrm{~b}$ \\
\hline CG.9 (dis) & $\ldots$ & $\ldots$ & $\ldots$ & $\ldots$ & $\ldots$ & $\ldots$ & $\ldots$ & $\ldots$ & $\ldots$ & $\ldots$ & 13 & $38 \mathrm{ab}$ \\
\hline CG.26 (dis) & 12 & $13 \mathrm{cdef}$ & $0 \mathrm{a}$ & 5 & $0 \mathrm{~b}$ & $0 \mathrm{a}$ & $8 \mathrm{~b}$ & $8 \mathrm{c}$ & $8 \mathrm{c}$ & $8 \mathrm{c}$ & 13 & $0 \mathrm{~b}$ \\
\hline CG.48 (dis) & 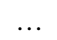 & $\ldots$ & & & $\ldots$ & & & 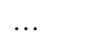 & $\ldots$ & & 9 & $33 \mathrm{ab}$ \\
\hline CG.60 (dis) & 9 & $5 \mathrm{i}$ & $0 \mathrm{a}$ & 0 & $0 \mathrm{~b}$ & $11 \mathrm{a}$ & $0 \mathrm{~b}$ & $0 \mathrm{c}$ & $0 \mathrm{c}$ & $0 \mathrm{c}$ & 13 & $15 \mathrm{ab}$ \\
\hline CG.67 (dis) & $\ldots$ & $\ldots$ & $\ldots$ & $\ldots$ & $\ldots$ & $\ldots$ & $\ldots$ & $\ldots$ & $\ldots$ & $\ldots$ & 13 & $0 \mathrm{~b}$ \\
\hline CG.103 (dis) & 12 & 12 defgh & $8 \mathrm{a}$ & 80 & $8 \mathrm{~b}$ & $50 \mathrm{a}$ & $25 \mathrm{ab}$ & $58 \mathrm{abc}$ & $58 \mathrm{abc}$ & $58 \mathrm{abc}$ & 12 & $33 \mathrm{ab}$ \\
\hline CG.132 (dis) & 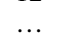 & & $\ldots$ & 年 & $\ldots$ & $\ldots$ & $\ldots$ & $\ldots$ & $\ldots$ & $\ldots$ & 12 & $8 \mathrm{~b}$ \\
\hline CG.134 (dis) & 11 & 12 defgh & $9 \mathrm{a}$ & 100 & $0 \mathrm{~b}$ & $9 \mathrm{a}$ & $0 \mathrm{~b}$ & $9 \mathrm{c}$ & $9 \mathrm{c}$ & $9 \mathrm{c}$ & 10 & $0 \mathrm{~b}$ \\
\hline CG.602 (dis) & 12 & 9 fghi & $8 \mathrm{a}$ & 100 & $8 \mathrm{~b}$ & $8 \mathrm{a}$ & $8 \mathrm{~b}$ & $8 \mathrm{c}$ & $8 \mathrm{c}$ & $33 \mathrm{bc}$ & 12 & $33 \mathrm{ab}$ \\
\hline CG.756 (dis) & $\ldots$ & $\ldots$ & $\ldots$ & $\ldots$ & $\ldots$ & $\ldots$ & $\ldots$ & $\ldots$ & $\ldots$ & $\ldots$ & 12 & $8 \mathrm{~b}$ \\
\hline CG.3029 (dis) & $\ldots$ & $\ldots$ & $\ldots$ & $\ldots$ & $\ldots$ & $\ldots$ & $\ldots$ & $\ldots$ & $\ldots$ & $\ldots$ & 6 & $0 \mathrm{~b}$ \\
\hline CG.5008 (dis) & 12 & 15 bcde & $8 \mathrm{a}$ & 81 & $0 \mathrm{~b}$ & $0 \mathrm{a}$ & $0 \mathrm{~b}$ & $0 \mathrm{c}$ & $0 \mathrm{c}$ & $0 \mathrm{c}$ & $\ldots$ & $\ldots$ \\
\hline CG.5156 (dis) & $\ldots$ & $\ldots$ & $\ldots$ & $\ldots$ & $\ldots$ & $\ldots$ & $\ldots$ & $\ldots$ & $\ldots$ & $\ldots$ & 10 & $0 \mathrm{~b}$ \\
\hline CG.6723 (dis) & 12 & $19 \mathrm{a}$ & $0 \mathrm{a}$ & 0 & $0 \mathrm{~b}$ & $0 \mathrm{a}$ & $0 \mathrm{~b}$ & $0 \mathrm{c}$ & $0 \mathrm{c}$ & $0 \mathrm{c}$ & 11 & $0 \mathrm{~b}$ \\
\hline CG.6737 (dis) & 6 & $11 \mathrm{efgh}$ & $0 \mathrm{a}$ & 0 & $0 \mathrm{~b}$ & $0 \mathrm{a}$ & $0 \mathrm{~b}$ & $0 \mathrm{c}$ & $0 \mathrm{c}$ & $17 \mathrm{c}$ & 14 & $0 \mathrm{~b}$ \\
\hline CG.8228 (dis) & $\ldots$ & $\ldots$ & $\ldots$ & $\ldots$ & $\ldots$ & $\ldots$ & $\ldots$ & $\ldots$ & $\ldots$ & $\ldots$ & 9 & $0 \mathrm{~b}$ \\
\hline
\end{tabular}

${ }^{\mathrm{n}}$ Fire blight of the rootstock was characterized by the presence of bacterial ooze on rootstock during the growing season and/or typical fire blight necrosis (black in color) with evidence of either tree death or premature leaf coloration in fall. $\mathrm{N}=$ number of trees in trial; $\ldots=$ rootstock not included in inoculation trial; $\mathrm{CG}=$ Cornell Geneva, advanced selection of apple rootstock breeding program of the USDA-ARS and Cornell University; EMLA = virustested clones developed at the East Malling and Long Ashton Research Stations, UK; VF = virus-free clone; $\mathrm{C}=$ clone grown at Cornell for several years.

${ }^{\circ}$ Trees were inoculated by spraying blossoms with Erwinia amylovora strain E4001a on 12 May 99 and 17 May 99.

p Fire blight rootstock infection resulting in commercial orchard after natural blossom blight epidemic that occurred May 2000.

${ }^{q}$ Percent trees with ooze present on rootstock. Values followed by the same letter did not differ significantly at $P=0.2$ as determined by Ryan's significance test for multiple comparison of proportions.

${ }^{\mathrm{r}}$ Rootstock blight; percent trees with symptoms of rootstock infection (blackish necrosis of rootstock usually accompanied by evidence of previous ooze, weak scion growth and/or premature leaf coloration in fall). Values followed by the same letter did not differ significantly at $P=0.2$ as determined by Ryan's significance test for multiple comparison of proportions.

${ }^{s}$ Percent dead or dying trees (failed to leaf out in the spring or initial leaves were small, yellowed and failed to continue growth). Values followed by the same letter did not differ significantly at $P=0.2$ as determined by Ryan's significance test for multiple comparison of proportions.

${ }^{\mathrm{t}}$ Percent blossom clusters with fire blight infection on 27 May 99. Values followed by the same letter did not differ significantly at $P=0.05$ as determined by a Waller-Duncan $k$-ratio $t$ test.

u Percent trees with fire blight infected rootstock suckers observed on 15 June 99 or 8 July 99 . Values followed by the same letter did not differ significantly at $P=0.2$ as determined by Ryan's significance test for multiple comparison of proportions.

${ }^{\vee}$ Shoot length blighted; percent rootstock sucker's current season's shoot length necrotic (mean of suckers with fire blight symptoms on 8 July 99 ).

${ }^{\text {w }}$ Trees on M.9 rootstock were grafted with 'McIntosh' rather than 'Royal Gala'.

${ }^{\mathrm{x}}$ Dead tree showed no symptoms of fire blight rootstock infection and was presumed to have died from other causes.

y Trees previously exhibiting symptoms of fire blight infection recovered and showed normal rootstock appearance and tree growth.

${ }^{\mathrm{z}}$ Selection discarded (dis) from breeding program. 
be similar to direct inoculation in the greenhouse. However, rootstock sucker infection occurred on only one tree each of B.9 and G.11 in the orchard trial; therefore, no conclusion can be reached.

It also is possible that other unknown environmental factors are responsible for the differences observed between greenhouse and orchard tests. Cline et al. (3) have reported that when vegetative shoots of M.7, B.9, and G.16 liners grown in a nursery were directly inoculated with strain E2017p, all three rootstocks were evaluated as moderately resistant, with approximately 40 to $50 \%$ of their shoot length becoming blighted. In the current study, B.9 was evaluated as highly susceptible, and M.7 and G.16 were evaluated as resistant when vegetative shoots of rootstock liners were directly inoculated in the greenhouse (Tables 3 and 4); however, the resistance of all three rootstocks appeared similar in orchard trials (Table 5).

There was general agreement in the evaluation of rootstock resistance in the controlled blossom inoculation trial and when rootstock infection resulted from natural blossom infection. High disease pressure in the natural infection block was indicated by the relatively high incidence of rootstock infection observed in M.7, MM.106, and MM.111 (Table 5) which are generally considered resistant or moderately resistant to fire blight (23). The lower-than-expected incidence of rootstock infection for M.9 in the natural infection block could have been due to a lower incidence of blossom infection in the earlier blooming McIntosh-type scion than in the Royal Gala trees, but accurate assessment of the incidence of blossom blight in individual trees was not made in this block. The virulence characteristics of the $E$. amylovora strain or strains that caused infection in the natural infection block are not known.

Compared with traditional plantings of large trees, high-density apple plantings on dwarfing rootstocks have many economic benefits, including higher yields, quicker return on investment, more efficient utilization of pesticide and labor inputs, and improved fruit quality. However, the increased planting costs of high-density plantings combined with the extreme fire blight susceptibility of M.9 and M.26 rootstocks has resulted in devastating financial losses for apple growers in some areas of the United States. We have calculated that, when the cost of tree replacement, lost investment in tree maintenance, and reduced yields over several years are considered, a $10 \%$ incidence of rootstock blight in a 4-year-old high-density planting can result in losses up to $\$ 3,500$ per acre (11). New apple rootstocks that combined desirable pomological characteristics with resistance to infection by E. amylovora have the potential to provide practical control for the rootstock phase of fire blight.

\section{ACKNOWLEDGMENTS}

We thank M. V. Bhaskara Reddy, D. Gill, and C. Bennett for their technical assistance; and J. Barnard for statistical advice.

\section{LITERATURE CITED}

1. Aldwinckle, H. S., and Preczewski, J. L. 1976. Reaction of terminal shoots of apple cultivars to invasion by Erwinia amylovora. Phytopathology 66:1439-1444.

2. Aldwinckle, H. S., Preczewski, J. L., and Beer, S. V. 1978. Differences in response of apple (Malus pumila) cultivars to inoculation with Erwinia amylovora. Pages 505-512 in: Proc. 4th Int. Conf. Plant Pathogenic Bacteria, Angers, France.

3. Cline, J. A., Hunter, D. M., Bonn, W. G., and Bijl, M. 2001. Resistance of the Vineland series of apple rootstocks to fire blight caused by Erwinia amylovora. J. Am. Pomol. Soc. 55:218-221.

4. Cummins, J. N., and Aldwinckle, H. S. 1994. Challenges to Malling 9, M.26 and M.7-new rootstocks from Geneva. Compact Fruit Tree 27:25-27.

5. Ferree, D. C. 1994. Performance after 8 years of 20 dwarfing rootstocks on 3 cultivars. Compact Fruit Tree 27:32-36.

6. Ferree, D. C., Hirst, P. M., Schmid, J. C., and Dotson, P. E. 1995. Performance of three apple cultivars with 22 dwarfing rootstocks during 8 seasons in Ohio. Fruit Var. J. 49:171178

7. Gardner, R. G., Cummins, J. N., and Aldwinckle, H. S. 1980. Fire blight resistance in the Geneva apple rootstock breeding program. J. Am. Soc. Hortic. Sci. 105:907-912.

8. Gardner, R. G., Cummins, J. N., and Aldwinckle, H. S. 1980. Inheritance of fire blight resistance in Malus in relation to rootstock breeding. J. Am. Soc. Hortic. Sci. 105:912-916.

9. Kado, C. I., and Heskett, M. G. 1970. Selective media for isolation of Agrobacterium, Corynebacterium, Erwinia, Pseudomonas, and Xanthomonas. Phytopathology 60:969-976.

10. Marini, R. P., Anderson, J. L., Autio, W. R., Barritt, B. H., Cline, J. A., Cowgill, W. P., Crassweller, R. M., Domoto, P. A., Ferree, D. C., Garner, J., Gaus, A., Greene, G. M.,
Hampson, P., Hirst, P., Kushad, M. N. Mielke, E., Mullins, C. A., Parker, M., Perry, R. L., Prive, J. P., Reighard, G. L., Robinson, T., Rom, C. R., Roper, T. R., Schupp, J. R., Stover, E., and Unrath, R. 2000. Performance of 'Gala' apple on 18 dwarf rootstocks: fiveyear summary of the 1994 NC-140 dwarf rootstock trial. J. Am. Pomol. Soc. 54:92-107.

11. Momol, M. T., Norelli, J. L., Breth, D. I., an Aldwinckle, H. S. 1999. Internal movement of Erwinia amylovora from infection in the scion and economic loss estimates due to the rootstock phase of fire blight of apple. Acta Hortic. 489:505-507.

12. Momol, M. T., Norelli, J. L., Piccioni, D. E. Momol, E. A., Gustafson, H. L., Cummins, J. N., and Aldwinckle, H. S. 1998. Internal movement of Erwinia amylovora through symptomless apple scion tissues into the rootstock. Plant Dis. 82:646-650.

13. NC-140. 1991. Performance of 'Starkspur Supreme Delicious' apples on 9 rootstocks at 27 sites over 10 years. Fruit Var. J. 45:200208.

14. Norelli, J. L., Aldwinckle, H. S., and Beer, S. V. 1984. Differential host $\times$ pathogen interactions among cultivars of apple and strains of Erwinia amylovora. Phytopathology 74:136139.

15. Norelli, J. L., Aldwinckle, H. S., and Beer, S V. 1986. Differential susceptibility of Malus spp cultivars Robusta-5, Novole and Ottawa523 to Erwinia amylovora. Plant Dis. 70:1017-1019.

16. Norelli, J. L., Aldwinckle, H. S., Beer, S. B., and Lamb, R. C. 1987. The effects of virulence of Erwinia amylovora on the evaluation of fire blight resistance in Malus. Phytopathology 77:1551-1555.

17. Paulin, J. P., Lachaud, G., and Lespinasse, Y. 1993. Role of the aggressiveness of strains of Erwinia amylovora in the experimental evaluation of susceptibility of apple cultivars to fire blight. Acta Hortic. 338:375-376.

18. Perry, R. L. 1990. Training and pruning the slender spindle and vertical axe tree. Proc. Annual Mass. Fruit Grow. Assoc. 96:87-98.

19. Quamme, H. A., and Bonn, W. G. 1981. Virulence of Erwinia amylovora and its influence on the determination of fire blight resistance of pear cultivars and seedlings. Can. J. Plant Pathol. 3:187-282.

20. Ryan, T. A. 1960. Significance tests for multiple comparison of proportions, variances, and other statistics. Phycol. Bull. 57:318-328.

21. Seemüller, E. A., and Beer, S. V. 1976. Absence of cell wall polysaccharide degradation by Erwinia amylovora. Phytopathology 66:433-436.

22. Steiner, P. W., and Suleman, P. 1993. A physiological model for fire blight symptom development in vegetative apple tissue infected by Erwinia amylovora. Acta Hortic. 338:217.

23. Van der Zwet, T., and Keil, H. L. 1979. Fire blight-A bacterial disease of rosaceous plants. U. S. Dep. Agric. Vol. Agric. Handbk. 510 . 